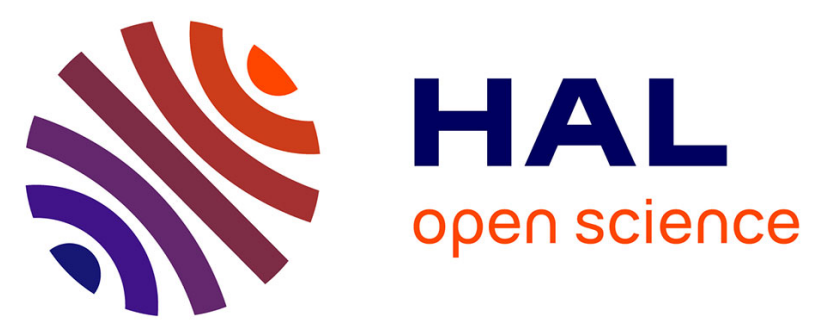

\title{
Dietary vitamin mix levels influence the ossification process in European sea bass (Dicentrarchus labrax) larvae
}

\author{
David Mazurais, M.J. Darias, Marie-Françoise Gouillou-Coustans, \\ Marie-Madeleine Le Gall, Christine Huelvan, Elizabeth Desbruyères, Patrick \\ Quazuguel, Chantal Cahu, José Zambonino Infante
}

\section{To cite this version:}

David Mazurais, M.J. Darias, Marie-Françoise Gouillou-Coustans, Marie-Madeleine Le Gall, Christine Huelvan, et al.. Dietary vitamin mix levels influence the ossification process in European sea bass (Dicentrarchus labrax) larvae. AJP - Regulatory, Integrative and Comparative Physiology, 2008, 294 (2), pp.R520-R527. 10.1152/ajpregu.00659.2007 . hal-02666638

\section{HAL Id: hal-02666638 https://hal.inrae.fr/hal-02666638}

Submitted on 31 May 2020

HAL is a multi-disciplinary open access archive for the deposit and dissemination of scientific research documents, whether they are published or not. The documents may come from teaching and research institutions in France or abroad, or from public or private research centers.
L'archive ouverte pluridisciplinaire HAL, est destinée au dépôt et à la diffusion de documents scientifiques de niveau recherche, publiés ou non, émanant des établissements d'enseignement et de recherche français ou étrangers, des laboratoires publics ou privés. 
D. Mazurais, M. J. Darias, M. F. Gouillou-Coustans, M. M. Le Gall, C. Huelvan, E. Desbruyères, P. Quazuguel, C. Cahu and J. L. Zambonino-Infante

Am J Physiol Regulatory Integrative Comp Physiol 294:520-527, 2008. First published Nov 21, 2007; doi:10.1152/ajpregu.00659.2007

You might find this additional information useful...

This article cites 27 articles, 4 of which you can access free at:

http://ajpregu.physiology.org/cgi/content/full/294/2/R520\#BIBL

Updated information and services including high-resolution figures, can be found at:

http://ajpregu.physiology.org/cgi/content/full/294/2/R520

Additional material and information about American Journal of Physiology - Regulatory, Integrative and Comparative Physiology can be found at:

http://www.the-aps.org/publications/ajpregu

This information is current as of September 7, 2010 .

The American Journal of Physiology - Regulatory, Integrative and Comparative Physiology publishes original investigations that illuminate normal or abnormal regulation and integration of physiological mechanisms at all levels of biological organization, ranging from molecules to humans, including clinical investigations. It is published 12 times a year (monthly) by the American

Physiological Society, 9650 Rockville Pike, Bethesda MD 20814-3991. Copyright @ 2008 by the American Physiological Society. ISSN: 0363-6119, ESSN: 1522-1490. Visit our website at http://www.the-aps.org/. 


\title{
Dietary vitamin mix levels influence the ossification process in European sea bass (Dicentrarchus labrax) larvae
}

\author{
D. Mazurais, M. J. Darias, M. F. Gouillou-Coustans, M. M. Le Gall, C. Huelvan, E. Desbruyères, \\ P. Quazuguel, C. Cahu, and J. L. Zambonino-Infante \\ Ifremer, Marine Fish Nutrition Team, Nutrition Aquaculture and Genomics Research Unit, UMR 1067, Ifremer, Technopole \\ Brest-Iroise, Plouzané, France
}

Submitted 12 September 2007; accepted in final form 19 November 2007

\begin{abstract}
Mazurais D, Darias MJ, Gouillou-Coustans MF, Gall MM, Huelvan C, Desbruyères E, Quazuguel P, Cahu C, ZamboninoInfante JL. Dietary vitamin mix levels influence the ossification process in European sea bass (Dicentrarchus labrax) larvae. Am J Physiol Regul Integr Comp Physiol 294: R520-R527, 2008. First published November 21, 2007; doi:10.1152/ajpregu.00659.2007.The influence of dietary vitamins on growth, survival, and morphogenesis was evaluated until day 38 of posthatching life in European sea bass larvae (Dicentrarchus labrax). A standard vitamin mix (VM), at double the concentration of the U.S. National Research Council's recommendations, was incorporated into larval feeds at $0.5 \%, 1.5 \%$, $2.5 \%, 4.0 \%$, and $8.0 \%$ to give treatments VM 0.5 , VM 1.5, VM 2.5, VM 4.0, and VM 8.0, respectively. The group fed the VM 0.5 diet all died before day 30. At day 38, the larvae group fed VM 1.5 had $33 \%$ survival, while the other groups, with higher vitamin levels, showed at least $50 \%$ survival. The higher the percentage VM in the diet, the lower the percentage of column deformities. High dietary vitamin levels positively influenced the formation of mineralized bone in larvae: the higher the dietary vitamin level, the higher the ossification status. In the larvae group fed at the highest vitamin levels, we observed a temporal sequence of coordinated growth factor expression, in which the expression of bone morphometric protein (BMP-4) preceded the expression of IGF-1, which stimulated the maturation of osteoblasts (revealed by high osteocalcin expression levels). In groups fed lower proportions of vitamins, elevated proliferator peroxisomeactivated receptors (PPAR- $\gamma$ ) expression coincided with low BMP-4 expression. Our results suggest that high levels of PPAR- $\gamma$ transcripts in larvae-fed diets with a low VM content converted some osteoblasts into adipocytes during the first two weeks of life. This loss of osteoblasts is likely to have caused skeletal deformities.
\end{abstract}

morphogenesis; bone differentiation; dietary vitamins; gene expression

VITAMINS ARE COMPOUNDS REQUIRED in trace amounts, for normal growth, health, and reproduction. Fish larvae reared in hatcheries usually obtain vitamins from the diets they are fed. Until now, most studies on vitamin requirements of fish have been conducted on juveniles, by feeding them chemically defined diets deficient in a specific vitamin (13). Data obtained on different fish species studied were compiled by the U.S. National Research Council (NRC) (17), and most of the standard vitamin mixtures available are based on this publication. Few studies exist on vitamin requirements in fish larvae, mainly because there were no efficient compound diets available for these developmental stages until recently. Fish larvae were previously fed live prey, which do not allow accurate determi-

Address for reprint requests and other correspondence: J. L. ZamboninoInfante, Ifremer Marine Fish Nutrition Team, Nutrition Aquaculture and Genomics Research Unit, UMR 1067, Ifremer, Technopole Brest-Iroise, BP 70, 29280 Plouzané, France (e-mail: jlzambon@ifremer.fr). nation of nutrient requirements. Considering the high growth rate during the larval period, it was assumed that vitamin requirements of fish larvae were higher than those of juveniles. Higher levels of standard vitamin mix (VM) were therefore incorporated into experimental larvae feeds on the basis of experience, the most common level used being 8 times the requirement of juvenile fish $(6,7)$. This strategy allowed the basic nutritional requirements of fish larvae in terms of proteins, lipids, and carbohydrates to be established, avoiding any possible vitamin deficiency risks $(3,19,28)$.

Over the last decade, many studies have reported the important influence that dietary vitamins have on the appearance of larval deformities. In particular, high dietary vitamin A was seen to negatively affect larval morphogenesis during the first weeks of life in Japanese flounder and European sea bass, through one of its active metabolites: retinoic acid $(4,23,25)$, which induces skeletal malformations. According to Villeneuve et al. $(25,26)$, this vitamin A effect on morphogenesis is mediated by retinoid nuclear receptors that disrupt the normal ontogenic expression pattern of genes involved in bone differentiation. Other dietary vitamins, such as vitamin D, can also induce vertebral deformities and hypermelanosis in Japanese flounder (10).

These results clearly demonstrate the necessity to accurately define dietary vitamin needs during the larval period. The development of a compound diet, which can totally and efficiently replace live prey, now allows studies to be made on the optimization of vitamin supply in feeds for marine fish larvae.

The aim of this study was therefore to test different levels of the same dietary VM during the development of European sea bass larvae, to observe the influence on their morphogenesis process. The first objective was the comparison of different morphological processes, to identify bone differentiation mechanisms that could be affected by dietary vitamins. The second objective was to determine the most appropriate level at which the standard VM should be incorporated into larvae feeds to induce good growth and survival but also harmonious morphological development.

\section{MATERIALS AND METHODS}

Animals and diets. Three-day old European sea bass (Dicentrarchus labrax) larvae were obtained from the Ecloserie Marine de Gravelines (Gravelines, France). The fish were acclimated and divided into fifteen 35-liter cylindroconical fiberglass tanks $(2,100$ larvae/tank) at a initial density of 60 larvae/liter. Tanks were supplied

The costs of publication of this article were defrayed in part by the payment of page charges. The article must therefore be hereby marked "advertisement" in accordance with 18 U.S.C. Section 1734 solely to indicate this fact. 
with through-flowing seawater, which had been previously filtered through a sand filter, then passed successively through a tungsten heater and a degassing column packed with plastic rings. Throughout the experiment, salinity was $35 \%$, and the oxygen level was maintained above $6 \mathrm{mg} / \mathrm{l}$ by setting the water replacement in the tank at up to $30 \%$ per hour (flow rate: $0.18 \mathrm{l} / \mathrm{min}$ ). Photoperiod was $24: 0-\mathrm{h}$ ligh-dark cycle, and light intensity was $9 \mathrm{~W} / \mathrm{m}^{2}$ maximum at the water surface. All procedures concerning the animals and their handling were conducted in compliance with the Guide for the Care and Use of Laboratory Animals (16). The study was performed under the licence no. 29.021 by the French Department of Veterinary Services (Direction Départementale des Services Vétérinaires) to conduct experimental protocols and samplings on fish.

To provide a wider range of dose levels and have more flexibility in the formula, we doubled the concentration of the standard VM (17). Consequently, $1 \%$ concentrated-vitamin mix used in this experiment corresponds to $2 \%$ standard VM. Microdiets were prepared in our experimental unit as previously described (3), and the pellet size was 200-400 $\mu \mathrm{m}$.

Five experimental groups (three replicates per group) of sea bass larvae were reared at $20^{\circ} \mathrm{C}$ and fed, from day 6 until day 38 posthatching, on microparticulate diets incorporating $0.5 \%$ (VM 0.5), $1.5 \%$ (VM 1.5), 2.5\% (VM 2.5), 4\% (VM 4.0), and 8\% (VM 8.0) of the concentrated VM. The composition of the VM is described in Table 1. Diet formulas were very close to that of a patented diet (WO 0064273), which includes $8 \%$ of the standard VM, equivalent to $4 \%$ of our concentrated VM. Throughout the experimental period, to allow the larvae to find the diet microparticles easily in the water column, they were continuously fed in large excess ( $24 \mathrm{~h}$ per day) using automatic belt feeders. As it is not possible to quantify the amount of food ingested by fish larvae, food ingestion was monitored under a binocular microscope by observing the filling of the digestive tract with dietary microparticles ( $1 \mathrm{~h}$ after feed distribution started).

Sampling. Thirty larvae were collected from each tank for weight measurement (formalin preserved) every week, and at the end of the experiment.

Larvae were sampled from each tank at 27 and 38 days posthatching $\left(n=30-50\right.$ larvae, depending on wet body wt) and kept at $-20^{\circ} \mathrm{C}$ for future enzyme assays. For each treatment, another 50 larvae were collected at days 9, 15, and 38, and total RNA was immediately extracted to measure the expression of some of the genes involved in larval development.

The incidence of skeletal malformations (head and vertebral column deformities) was determined by sampling $n=2038$-day-old larvae per tank. These larvae were stained with Alcian blue and Alizarin red S to color cartilage and bone areas, respectively. Survival was evaluated by counting the individuals in each tank at the end of the experiment.

Image analysis. Colored larvae were put on a glass plate containing glycerol and directly scanned using a desk scanner (Epson Perfection 4990 Photo). A 2,500-kb picture was then created.

Six readers made separate overall analyses of the deformities of the spinal column (cyphosis, lordosis, number of vertebrae) and the head (prognatism). The results were compiled and statistically analyzed as described below.

Individual size and the surfaces corresponding to cartilage and bone in whole larvae (day 38) were visualized and quantified using a computerized image analysis package (IMAQ Vision Builder, National Instruments, Austin, TX) after staining with Alcian blue and Alizarin red S. The larvae from the various groups (VM 1.5, 2.5, 4.0, 8.0) were treated simultaneously during the coloration to avoid any bias due to technical variability. The scripting feature of IMAQ Vision Builder was used to record a series of image-processing steps and their specific parameters, so that the computerized image analyses were also performed simultaneously for all samples (batch processing). The script used a list of image-processing commands encompassing the selection of pixel color range and quantification. Selecting ranges of pixel values in color images (threshold operations) allowed the pixels associated with red (bone) or blue (cartilage) colorations to be distinguished. The number of selected pixels was then quantified using a particle analyses operation. Larval size was quantified by calculating the surface area (in pixels) covered by whole stained larvae.

Analytical methods. Total RNA was extracted using TRIzol and reverse-transcribed in duplicate (iScript cDNA Synthesis Kit; BioRad Laboratories, Hercules, CA). These duplicates were then pooled. Quantitative PCR analyses for each gene were performed in triplicate in a total volume of $15 \mu \mathrm{l}$ containing $5 \mu \mathrm{l}$ cDNA (dilution: $10^{-2}$ ), 0.5 $\mu l$ primers $(10 \mu \mathrm{mol} / \mathrm{l}), 7.5 \mu \mathrm{l}$ iQ SYBR Green supermix 2X (BioRad Laboratories), and $2 \mu$ l sterile water. For each target gene [bone

Table 1. Composition (in \%) of the diets

\begin{tabular}{|c|c|c|c|c|c|}
\hline & VM 0.5 & VM 1.5 & VM 2.5 & VM 4.0 & VM 8.0 \\
\hline Defatted fish meal $\dagger$ & 52.0 & 52.0 & 52.0 & 52.0 & 52.0 \\
\hline Soy lecithin & 7.0 & 7.0 & 7.0 & 7.0 & 7.0 \\
\hline Marine lecithin & 14.0 & 14.0 & 14.0 & 14.0 & 14.0 \\
\hline Concentrated vitamin mix & 0.5 & 1.5 & 2.5 & 4.0 & 8.0 \\
\hline Mineral mix§ & 4.0 & 4.0 & 4.0 & 4.0 & 4.0 \\
\hline \multicolumn{6}{|c|}{ Proximal composition } \\
\hline Dry matter & 87.0 & 86.7 & 87.2 & 87.1 & 87.7 \\
\hline Proteins & 62.1 & 64.0 & 64.7 & 64.8 & 65.8 \\
\hline Lipids & 21.0 & 20.8 & 21.3 & 20.4 & 21.1 \\
\hline Neutral lipids & 5.6 & 5.4 & 5.6 & 4.7 & 5.3 \\
\hline
\end{tabular}

*All dietary ingredients were obtained commercially. Fish meal hydrolysate CPSP 90:10\% lipids; Soluble Fish Protein Concentrate (Sopropêche, Boulogne sur Mer, France); soy lecithin (Ets Louis François, St. Maur des Fossés, France); marine lecithin LC 60 (Phosphotech, St. Herblain, France). $†$ Defatted in the laboratory using Norse LT 94 fish meal (La Lorientaise, Lorient, France). $\$$ Composition per kilogram of the vitamin mixture: choline chloride $60 \%, 333$ g; vitamin A acetate, $(500000 \mathrm{UI} / \mathrm{g}) 1 \mathrm{~g}$; vitamin E (500 UI/g) $20 \mathrm{~g}$; vitamin D3 (500,000 UI/g) 0.96 g; vitamin B3 2 g, vitamin B5 4 g; vitamin B1 200 mg; vitamin B2 80\%, $1 \mathrm{~g}$; vitamin B6 $600 \mathrm{mg}$; vitamin C 35\%, $28.6 \mathrm{~g}$; vitamin B9 80\%, $250 \mathrm{mg}$; vitamin concentrate B12 (10 g/kg), $0.2 \mathrm{~g}$; biotin, $1.5 \mathrm{~g}$; vitamin K3 $51 \%, 3.92 \mathrm{~g}$; meso-inositol $60 \mathrm{~g}$; cellulose, $542.4 \mathrm{~g}$. §Composition per kilogram of the mineral mixture: $90 \mathrm{~g} \mathrm{KCl}, 40 \mathrm{mg} \mathrm{KIO} 3,500 \mathrm{~g} \mathrm{CaHPO}_{4} 2 \mathrm{H}_{2} \mathrm{O}, 40 \mathrm{~g} \mathrm{NaCl}_{3} 3 \mathrm{~g} \mathrm{CuSO} 45 \mathrm{H}_{2} \mathrm{O}$, $4 \mathrm{~g} \mathrm{ZnSO}_{4} 7 \mathrm{H}_{2} \mathrm{O}, 20 \mathrm{mg} \mathrm{CoSO}_{4} 7 \mathrm{H}_{2} \mathrm{O}, 20 \mathrm{~g} \mathrm{FeSO}_{4} 7 \mathrm{H}_{2} \mathrm{O}, 3 \mathrm{~g} \mathrm{MnSO}_{4} \mathrm{H}_{2} \mathrm{O}, 215 \mathrm{~g} \mathrm{CaCO}_{3}, 124 \mathrm{~g} \mathrm{MgSO}_{4} 7 \mathrm{H}_{2} \mathrm{O}$, and $1 \mathrm{~g} \mathrm{NaF}$. VM, vitamin mix. 
morphogenetic protein 4 (BMP-4), IGF-1, osteocalcin, retinoid X receptor alpha $(\operatorname{RXR} \alpha)$, retinoic acid receptor alpha $(\operatorname{RAR} \alpha)$, and peroxisome proliferator-activated receptor gamma (PPAR $\gamma$ )], specific complementary primers designed from previously cloned sequences are listed in Table 2. The housekeeping gene Efl was chosen as a reference since it did not exhibit any significant variation in expression among the samples. Thermal cycling was initiated with incubation at $95^{\circ} \mathrm{C}$ for 3 min to activate iTaq DNA polymerase. After this initial step, 45 cycles of PCR were performed. Each PCR cycle consisted of heating for $30 \mathrm{~s}$ at $95^{\circ} \mathrm{C}$ for denaturation, then for $1 \mathrm{~min}$ at $60^{\circ} \mathrm{C}$ for annealing and extension. Cycle threshold (CT) values corresponded to the number of cycles at which the fluorescence emission monitored in real time exceeded the threshold limit. Melting curve analysis was performed to confirm production of a single product in these reactions, and the products were sequenced by MilleGen (Labège, France). Standard curves were established for each gene by plotting CT values against the $\log _{10}$ of five different dilutions (in triplicate) of cDNA sample solutions. Real-time PCR efficiencies were determined for each gene from the slopes obtained with Bio-Rad software, applying the equation $E=10^{[-1 / \text { slope }]}$, where $E$ is PCR efficiency. To determine the relative quantity of target gene-specific transcripts present in the different samples, expression ratios $(R)$ were calculated according to the following formula:

$$
R=\frac{\left(E_{\text {target genen }}\right)^{\Delta \mathrm{CT} \text { target gene (mean sample }- \text { mean ref sample) }}}{\left(E_{\mathrm{Ef} 1}\right)^{\Delta \mathrm{CT} \text { Ef1 (mean sample }- \text { mean ref sample) }}}
$$

where Ef1 is the housekeeping gene, mean sample corresponds to triplicate average, and ref sample was chosen in the VM 4.0 group.

Statistics. Results are expressed as means \pm SD. Survival rates, malformation rates, and bone/cartilage ratios were normalized by arcsin square root transformation and were analyzed by one-way ANOVA with Statview followed by the Newman-Keuls test when significant differences were found at the $P<0.05$ level. Gene expression data, excluding the VM 0.5 group that died during the experiment, were analyzed by two-way ANOVA followed by Newman-Keuls tests when significant differences were found at the $P<$ 0.05 level.

To analyze VM 0.5 results for specific genes, we performed one-way ANOVAs on day 9, day 15, and day 38.

\section{RESULTS}

Larval performance. All of the experimental feeds were efficiently ingested by the larvae. The larvae fed at the lowest vitamin level, VM 0.5 diet, had all died by day 30. At day 38, the groups fed VM 2.5, VM 4.0, and VM 8.0 diets all had survival rates higher than $50 \%$ though (Table 3) and significantly higher from that of the VM 1.5 group (33\%). In terms of

Table 2. Oligonucleotide primers used in real-time PCR

\begin{tabular}{|c|c|c|}
\hline Genes & Accession Number & Forward and Reverse Primers \\
\hline \multirow[t]{2}{*}{ BMP4 } & AJ567451 & F: CTGCTCTCTTCCGCTGAACT \\
\hline & & R: GGCTCACATCAAAGCTCTCC \\
\hline \multirow[t]{2}{*}{ IGF-1 } & AY800248 & F: GTCTTGGCAGGTGCACAGCA \\
\hline & & R: ACACGCTGCAGTTTGTGTGT \\
\hline \multirow{2}{*}{ Osteocalcin } & AY663813 & F: ATGGACACGCAGGGAATCATTG \\
\hline & & R: TGAGCCATGTGTGGTTTGGCTT \\
\hline \multirow[t]{2}{*}{$\mathrm{RXR} \alpha$} & AJ567907 & F: CTGGTAGAGTGGGCCAAGAG \\
\hline & & R: GTTCTGTGAGCACCCTGTCA \\
\hline \multirow[t]{2}{*}{$\operatorname{RAR} \alpha$} & AJ496189 & F: CGCTAAACCGAACCCAGA \\
\hline & & R: CTTCTCGGCCTGTTCCAA \\
\hline \multirow[t]{2}{*}{ PPAR $\gamma$} & AY590303 & F: CAGATCTGAGGGCTCTGTCC \\
\hline & & R: CCTGGGTGGGTATCTGCTTA \\
\hline \multirow[t]{2}{*}{ Ef1 } & AJ866727 & F: GCTTCGAGGAAATCACCAAG \\
\hline & & R: CAACCTTCCATCCCTTGAAC \\
\hline
\end{tabular}

weight, the VM 1.5 group also had the lowest performance (29.8 mg), while groups fed diets VM 4.0 and VM 8.0 showed $30 \%$ higher weight (Table 3). The same trend was observed with larvae length (Table 3), although the differences were less pronounced (only a 14\% difference in length between the VM 1.5 and VM 8.0 groups).

All of the experimental groups exhibited a statistically similar percentage of head deformities, mostly because of the very high variability (Fig. 1). The higher the dietary level of VM, the lower the percentage of column deformities $(P<0.0001)$, although no significant difference was observed between VM 4.0 and VM 8.0. The percentage of column deformities decreased by a factor of 3.5 between the groups fed the VM 1.5 and 8.0 diets $(P<0.001)$.

Bone/cartilage ratio was analyzed to evaluate the ossification process in larvae (Fig. 2). The high dietary vitamin levels increased the formation of mineralized bone in larvae: the higher the dietary vitamin level, the higher the ratio $(P<0.001)$.

Gene expression. BMP-4 expression was effectively halved between day 9 and day $38(P<0.0001)$. This decrease was much more pronounced $(2.9$ times; $P<0.0001)$ in larvae fed the low-vitamin diets, i.e., lower than $4.0 \%$ (Fig. 3). One-way ANOVAs of BMP-4 expression at days 9, 15, and 38 indicated that the larvae groups fed diets with low vitamin mix levels exhibited the lowest values $(P=0.017, P<0.006$, and $P=$ 0.011 for days 9,15 , and 38 , respectively). In contrast, there was at least a 10-fold increase in IGF-1 expression at day 38 compared with day $9(P<0.001)$. The only significant influence of dietary vitamin level was noted at day 38 in group VM 4.0, where IGF-1 showed a relative expression 1.8 times higher (Fig. 4, effect of diet $P<0.0001$ and diet $\times$ age interaction $P=0.0001)$ than the three other groups. Similarly, an elevation of osteocalcin expression (by at least 20 times) occurred during the experiment $(P<0.001)$, although the greatest increase happened after day $15(P<0.001)$ (Fig. 5). The highest osteocalcin expression values were noted in larval groups fed the highest dietary vitamin levels $(P=0.0009)$, but this influence of diet was only shown at day 38 (diet $\times$ age interaction $P=0.0003$ ). One-way ANOVA analysis revealed that the osteocalcin expression in group VM 8.0 was $1.5,1.8$, and 2 times higher than in groups VM 4.0, 2.5, and 1.5, respectively $(P=$ $0.0086)$. It should be added that, at day 38 , bone/cartilage ratios were highly correlated with osteocalcin expression data $(Y=$ $\left.0.534 \cdot \mathrm{X}+4.756 ; R^{2}=0.961 ; P=0.019\right)$.

$\mathrm{RXR} \alpha$ expression levels increased with age $(P=0.0002)$ but, once again, more markedly after day $15(P<0.0005)$ (Fig. $6)$. The influence of diet was clearly shown at days 9 and 38 $(P=0.0002)$ when the highest $\mathrm{RXR} \alpha$ values were measured in larvae groups fed VM 4.0 and VM 8.0. One-way ANOVA analysis showed that the expression of $\operatorname{RXR} \alpha$ in both the VM 4.0 and 8.0 groups was over 2.5 and 5 times higher than the other groups, at days 9 and 38, respectively.

A sharp decrease in RAR $\alpha$ expression occurred between day 9 and $38(P<0.0001)$ (Fig. 7), which was more marked in groups VM 1.5 and VM 2.5 (50\% decrease) than in groups VM 4.0 and 8.0 (30\% decrease), revealing an effect of dietary vitamin level on this parameter $(P=0.0001)$.

PPAR $\gamma$ expression increased with age after day 9, doubling by the end of the experiment $(P<0.0001)$ (Fig. 8). The expression of PPAR $\gamma$ was also positively influenced by the 
Table 3. Growth and survival rates of larvae fed the experimental diets at day 38

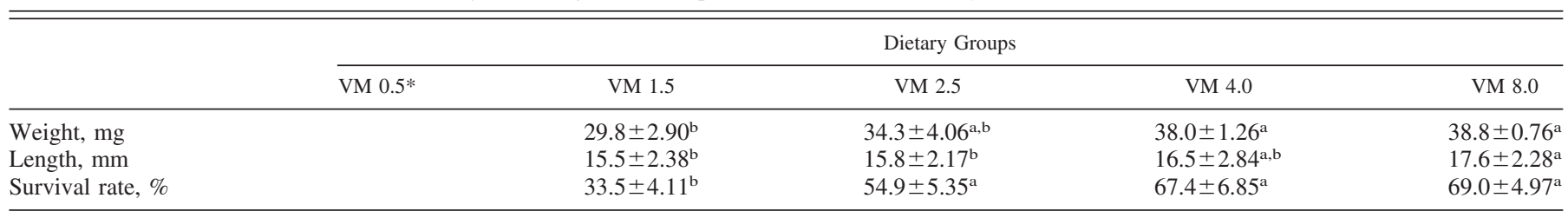

Values are expressed as means \pm SD. ${ }^{\text {a,b }}$ Different superscript letter in the same row are significantly different $(P<0.05)$. $*$ All larvae died on the VM 0.5 diet.

VM 1.5 and 2.5 diets $(P<0.0001)$, with the maximum effect at day 15 (diet $\times$ age interaction $P<0.0001)$.

One-way ANOVA of PPAR $\gamma$ expression at day 9 and at day 15 indicated that the larvae groups fed diets with low VM levels exhibited values 1.9 and 2.9 times higher than those found in groups fed the two highest dietary vitamin mix levels ( $P=0.0002$ and $P<0.0001$ for days 9 and 15 , respectively). At day 38 this effect, induced by low dietary vitamin mix, is less marked.

\section{DISCUSSION}

In fish, the dietary vitamin requirement has classically been determined in juvenile fish on the basis of their weight gain and absence of deficiency signs. As vitamin requirements are affected by various environmental, physiological, and nutritional interrelationships, fairly wide ranges of requirement values have been reported for the same species (17) because of differences in experimental conditions. Moreover, these same wide value ranges established for juveniles have also been considered empirically valid for earlier developmental stages (though an additional safety margin of extra vitamins is generally added). The fact that neck deformities and vertebral and spinal disorders occur with a high frequency and variability in marine fish hatcheries (15) reveals that this empirical approach is not satisfactory. Recent studies on fish larvae have provided clear evidence for the influence of dietary nutrients, and more particularly vitamins, on their developmental processes (10, 26). These results underline the need to improve our understanding of true dietary vitamin requirements during the larval period and refine vitamin dosing by taking into account parameters other than just weight or survival. The measurement of certain indicators of bone differentiation can be used to monitor for the appearance of deformities, so as to reduce these

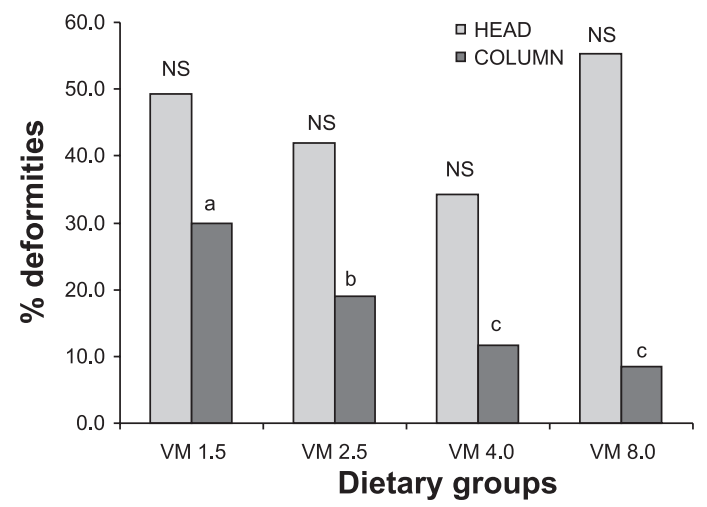

Fig. 1. Percentage of head and column deformities in 38-day-old sea bass larvae fed the different experimental diets. For each type of deformity, values are presented as means \pm S.D. ${ }^{\text {a,b,c }}$ Differing letters denote significant difference $(P<0.05)$. VM, vitamin mix; NS, nonsignificant. as much as possible. Moreover, such studies should also use feed ingredients that do not contain significant amounts of vitamins. Larval feeds traditionally contain fish meal, which mainly provides a source of protein but which also contains significant and variable amounts of other nutrients, such as fatty acids, minerals, and vitamins (particularly liposoluble vitamins $\mathrm{A}, \mathrm{D}, \mathrm{E}$, and $\mathrm{K}$ ). To overcome possible vicariance (underestimation of one vitamin requirement when others are present in excess), we decided to produce a defatted fish meal that improved our control over the liposoluble vitamin supply, particularly that of vitamins $\mathrm{A}$ and $\mathrm{D}$, which are known to influence bone differentiation. Essential fatty acids were supplied using purified marine phospholipids, containing only traces of vitamins A and E. The experimental diet formula used in this work was very similar to that of a patented diet known to induce good development in fish larvae (3), even though a certain and variable percentage of deformities are still observed, and this diet allowed us to examine the physiological effects of variation in dietary vitamin levels.

Studies testing the effect of different levels of vitamin mix on fish larvae are scarce. Escaffre et al. (6) showed that a diet with 5\% standard VM led to better growth performance than one with $2 \% \mathrm{VM}$ in common carp larvae. However, our present study is the first to test such a large range of incorporation levels of the standard VM into larval feeds. Past studies have described the effects of vitamins A $(4,5,6,24,25), C$ (7), or D (10) on fish larval development. Among these, vitamin A has been the most studied, not only for growth and survival but also to identify the molecular processes leading to the appearance of deformities. Consequently, comparisons could be made between these studies and our own by examining this particular vitamin. Villeneuve et al. (25) reported a negative effect of high and low dietary vitamin A level on growth and survival in European sea bass larvae that were fed diets incorporating retinol acetate at $1,000 \mathrm{mg} / \mathrm{kg}$ diet or less than $50 \mathrm{mg} / \mathrm{kg}$ diet

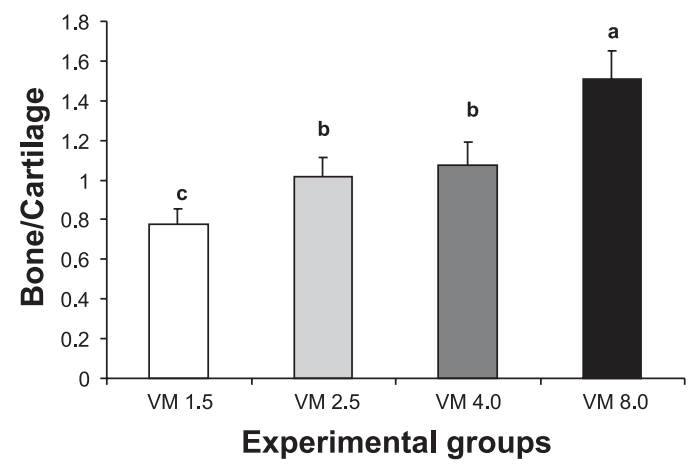

Fig. 2. Bone/cartilage ratio in 38-day-old sea bass larvae fed the different experimental diets. Values are presented as means \pm SD. ${ }^{a, b, c}$ Differing letters denote significant difference $(P<0.05)$. 


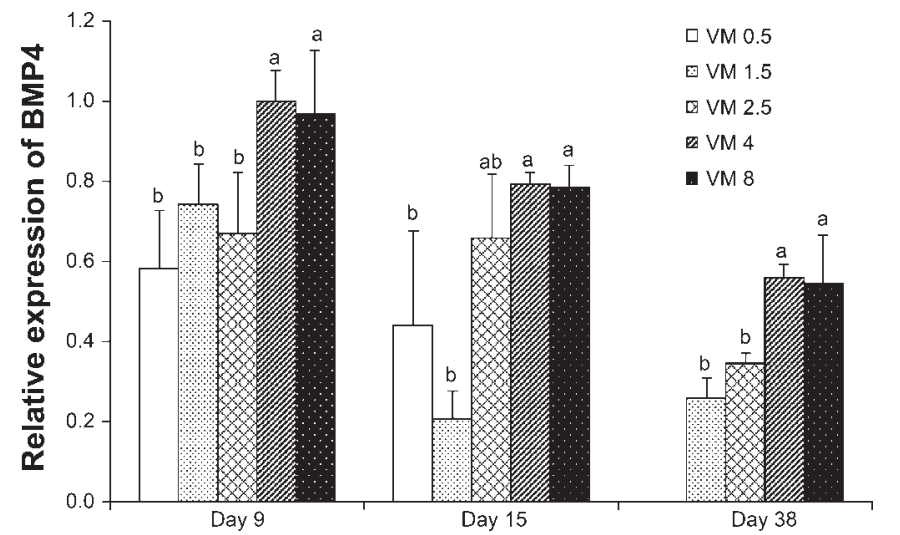

Fig. 3. Relative expression of the bone morphogenetic protein-4 (BMP-4) gene during the development of sea bass larvae fed the different experimental diets. For each developmental date, values are presented as means $\pm \mathrm{SD}$. ${ }^{\mathrm{a}, \mathrm{b}}$ Differing letters denote significant difference $(P<0.05)$.

(500,000 USP U/g), respectively. The highest level tested by these authors would correspond to 10 times our highest level of vitamin A (diet VM 8.0), and their lowest levels would correspond to our diets VM 1.5 and VM 2.5. Villeneuve et al. (25) only found a slight negative effect on larvae survival when feeding diets with an intermediate level of vitamin A: $250 \mathrm{mg}$ retinol acetate $/ \mathrm{kg}$ diet. Dedi et al. (4) observed negative effects on growth of flounder larvae fed live prey enriched with different vitamin A-palmitate levels, above $416 \mathrm{IU} / \mathrm{g}$, which correspond approximately to the vitamin A level found in VM 4.0. Other authors $(5,18)$ also described adverse effects of high dietary vitamin A levels on growth. The upper range of dietary VM levels tested in our experiment was obviously too low, compared with the extremely high values reported in the literature, to evidence any adverse effect of hypervitaminosis on growth and survival. In our experiment, growth (length and weight) and survival were only negatively influenced by diets incorporating less than $2.5 \% \mathrm{VM}$, corresponding to a hypovitaminosis. Considered together, these data indicate that growth and survival parameters are not sensitive enough to reveal any effect of the dietary VM when this varied within a "normal range," as it can do in commercial feeds.

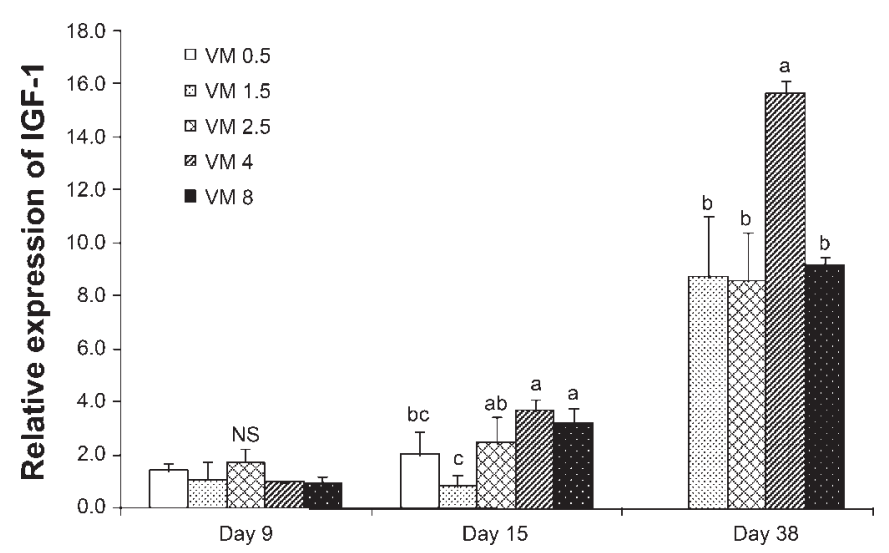

Fig. 4. Relative expression of the IGF-1 gene during the development of sea bass larvae fed the different experimental diets. For each developmental date, values are presented as means \pm SD. ${ }^{a, b, c}$ Differing letters denote significant difference $(P<0.05)$.

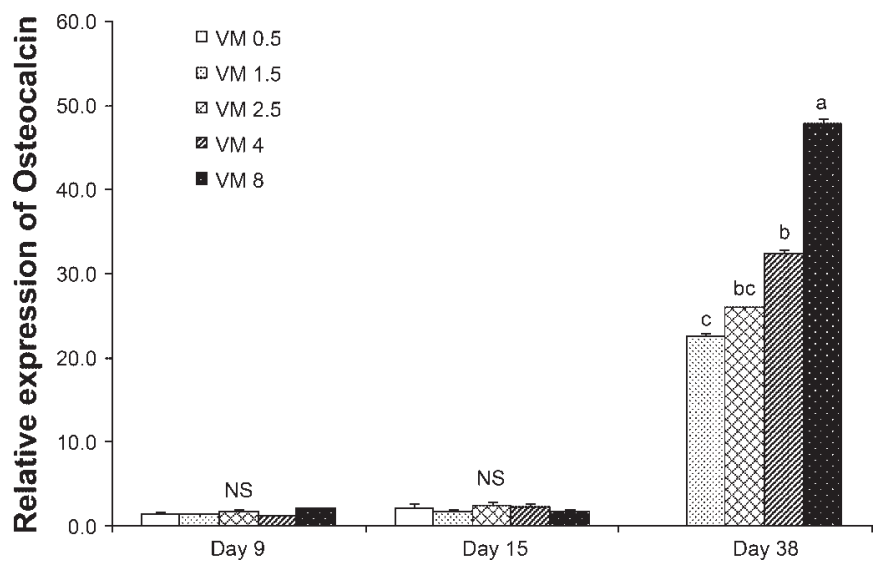

Fig. 5. Relative expression of the osteocalcin gene during the development of sea bass larvae fed the different experimental diets. For each developmental date, values are presented as means \pm SD. ${ }^{a, b, c}$ Differing letters denote significant difference $(P<0.05)$.

The elevation of the vitamin A level in larvae feeds generally induced a higher percentage of larvae deformities. Villeneuve et al. (25) found almost $20 \%$ head deformities with a 50 $\mathrm{mg}$ retinol acetate $/ \mathrm{kg}$ diet, a level that would correspond to our VM 4.0 diet. Dedi et al. (4) and Takeuchi et al. (24) found that high dietary vitamin A levels adversely affected the vertebral development of fish. In the present experiment, this adverse effect of high dietary vitamin levels on the column was not noted since the upper levels of vitamin tested in our experiment corresponded to medium/normal levels of vitamins in the studies reported by the literature. We found a high level of head deformities whatever the dietary vitamin level, which could suggest that vitamins do not influence head morphogenesis (although this is unlikely considering the data in the literature) or that there was an inadequate proportion of certain vitamins in the mixture. However, we simultaneously observed a lower occurrence of column deformities and a more intense ossification process in larvae fed the diets with the higher percentages of vitamin mix. This result constitutes an original finding and suggests that dietary VM level affects the differentiation of vertebral column bone cells at early stages of fish larval development. The formation of the vertebral column in

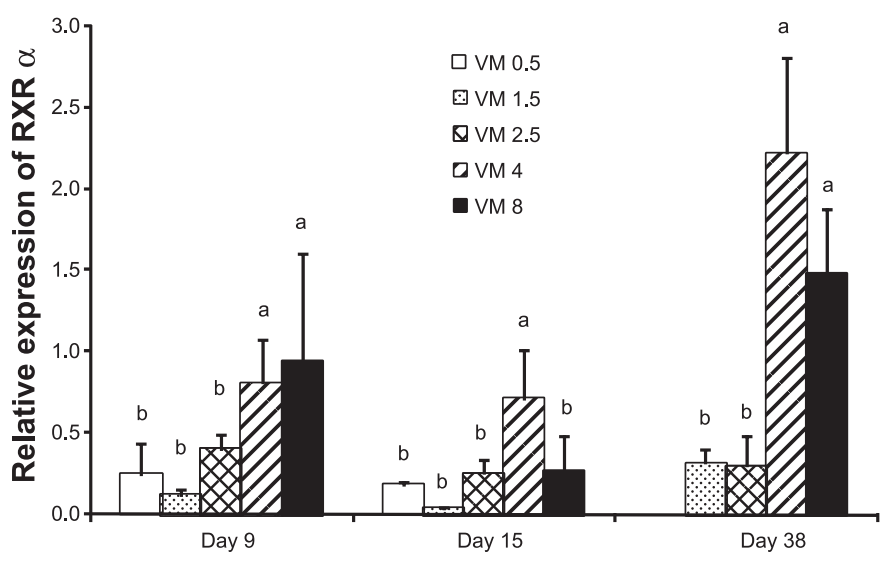

Fig. 6. Relative expression of the retinoic acid receptor alpha (RXR- $\alpha$ ) gene during the development of sea bass larvae fed the different experimental diets. For each developmental date, values are presented as means \pm SD. ${ }^{\mathrm{a}, \mathrm{b}}$ Differing letters denote significant difference $(P<0.05)$. 


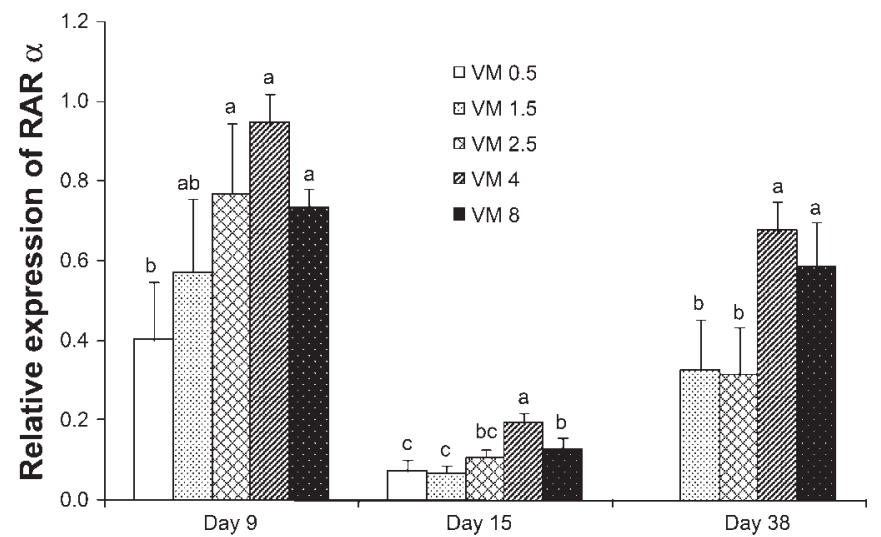

Fig. 7. Relative expression of the retinoid acid receptor (RAR)-alpha gene during the development of sea bass larvae fed the different experimental diets. For each developmental date, values are presented as means \pm SD. ${ }^{\text {a,b,c Dif- }}$ fering letters denote significant difference $(P<0.05)$.

teleost fish occurs by intramembranous ossification, in which bone is formed as a bone matrix and directly ossified (9). The cranial bone is formed by endochondoral ossification, however, in which bone is first formed as cartilage and then ossified into mineralized bone during larval development (23). These physiological differences between dermal head bone cells and vertebral column bone cells may explain the fact that the development of bone in the head and the vertebral column is not affected in the same way by the dietary vitamin mix.

Among the vitamins contained in the vitamin mix, vitamins $\mathrm{A}, \mathrm{C}, \mathrm{D}$, and $\mathrm{K}$ particularly influence the formation of bone (15). The biological activity of vitamin A is mainly mediated by its active metabolite retinoid acid, obtained by the dehydrogenation of vitamin A. Some important functions of vitamin A include regulation of cellular differentiation and proliferation and regeneration of rhodopsin that is necessary for vision. Vitamin A regulates skeletogenesis and cartilage development by controlling chondrocyte function. Vitamin $\mathrm{C}$ is a cofactor in many biological processes of cells involved in hormonal and immunological responses, including a role in the formation of structural components such as bone matrices, collagen, and connective tissue synthesis (15). The physiological role of vitamin $\mathrm{D}_{3}(1,25$-dihydroxy vitamin $\mathrm{D})$ in fish is not clearly defined although, as in mammals, it seems to be involved in intestinal calcium and phosphate absorption and also to have a direct effect on bone (15). Vitamin $\mathrm{K}$ is specially known for its effect on blood clotting, but it also has a role in stimulating bone formation and inhibiting resorption (15).

The biological effects of vitamin A metabolites are mainly exerted through the activation of two groups of nuclear receptors: RARs and RXRs, with different retinoid acid isomer specificity (20). Similarly, vitamin $\mathrm{D}_{3}$ signaling is dependent on the vitamin D receptors (VDR) (12). VDR receptors function by forming obligate heterodimers with RXR, which are then involved in nearly all processes associated with development, emphasizing the pivotal role of the retinoid pathway in the signaling network (29). These heterodimers can bind to the response elements of vitamin $\mathrm{D}$ or to retinoid acid localized on target genes and thereby suppress or enhance the transcription of more than 500 genes either directly or indirectly (2).

Skeleton cells are derived from different embryonic lineages and include cartilage and bone tissue types, with three types of cells: chondrocyte in the cartilage, osteoblasts or bone-forming cells, and osteoclasts or bone-resorbing cells in the bone (13). It is now well established that cell differentiation into chondrocytes or osteoblasts and subsequent cartilage and bone formation are processes governed by several growth factors and their intracellular signals (27), both of which can, in turn, be modulated by nutritional factors. For example, a possible effect of vitamin A on chondrocyte differentiation has already been observed in fish larvae. Suzuki et al. $(22,23)$ reported that Japanese flounder larvae exposed to retinoic acid at a concentration above $10^{-7} \mathrm{M}$ show a depressed expression of sonic hedgehog (shh) and Hoxd-4 and reduce the scale of expansion of shh expression domains in the pharyngeal area. Pharyngeal cartilages that formed in these larvae were malformed. The period when shh expression domains expand corresponds to the stage of active proliferation of the cartilage precursor cells and their differentiation into chondrocytes (23). The malformations observed by Suzuki et al. (23) were attributed to a misregulation of the shh signaling pathway in the head area.

Osteoblasts are derived from multipotent mesenchymal stem cells that give rise to osteoblastic progenitor cells. These then undergo proliferation/amplification before final differentiation and expression of specific osteoblastic markers (11).

In the present experiment, we found a temporal sequence of coordinated growth factor expression. Indeed, the expression of BMP-4, a potent osteoblast differentiation factor, was more elevated during the earliest larval developmental stages than later on, and its expression was positively modulated by the level of dietary vitamins. This pattern of expression is in agreement with a primary effect of BMP-4 on the multipotent cells, and the high expression of BMP-4 can cause these cells to commit to an osteoblastic pathway. At a later developmental stage (from day 15 onward), we observed an elevation in the expression of IGF-1, which was more marked when the diets contained high levels of vitamins. Considering that IGF increases proliferation and plays a major role in stimulating mature osteoblast function (11), our result suggests that IGF promoted the late-stage differentiation of sea bass larvae osteoblasts in a dose-dependent manner, according to the level of dietary vitamins. Indeed, IGF expression preceded the expression of osteocalcin by several days. Osteocalcin, which is probably the most, if not the only osteoblast-specific gene (13),

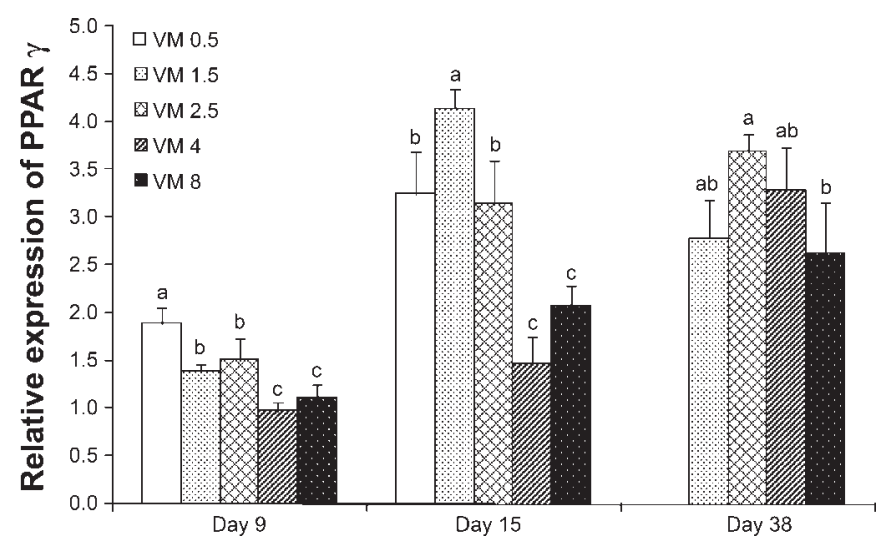

Fig. 8. Relative expression of the peroxisome proliferator-activated receptor- $\gamma$ (PPAR- $\gamma$ ) gene during the development of sea bass larvae fed the different experimental diets. For each developmental date, values are presented as means \pm SD. ${ }^{\mathrm{a}, \mathrm{b}, \mathrm{c}}$ Differing letters denote significant difference $(P<0.05)$. 
was not regulated by the dietary vitamin level until day 15 . Osteocalcin, moreover, displayed a constant low expression level until day 28 (result not shown). The positive impact of the high dietary vitamin levels on osteoblast differentiation is shown clearly at day 38 by both osteocalcin gene expression and red alizarin coloration of bones. It is interesting to note that the high correlation between osteocalcin expression and red alizarin coloration of mineralized bone tissue at day $38 \mathrm{dem}-$ onstrates that this gene is a good indicator of bone differentiation and can be used to investigate ossification status in whole body larvae homogenates.

We also found that larvae groups fed a low vitamin level and exhibiting a low expression of the BMP-4 gene had a concomitantly elevated expression of PPAR- $\gamma$. This result is interesting since it has been shown that osteoblastic cells, when transfected with PPAR- $\gamma$, can be converted to express an adipocytic phenotype (1). The possibility that a differentiated osteoblastic cell subsequently redifferentiates as a distinct phenotype is supported by the existence of bipotent osteoblastadipocyte cells from bone marrow in several species (11). It is also interesting to note that, in our experiment, the high expression levels of BMP-4 were associated with high expression levels of RAR $\alpha$ and RXR $\alpha$ in larvae groups fed the diets with elevated vitamin content. This result reflects a higher retinoid acid content in these larvae, since the expression of retinoid receptors is known to be modulated by the level of retinoic acid (25) that was obviously higher in groups fed the diets with elevated vitamin levels. Considering that retinoid acid inhibits adipose conversion and acts with BMP to promote osteoblast differentiation, our findings suggest that larvae that were fed diets with low VM content and expressing high levels of PPAR- $\gamma$ transcripts, have had part of their osteoblast potential converted into adipocytes during the first two weeks of life. This loss of osteoblasts is a likely cause of skeletal deformities.

In conclusion, this study has indicated that fish larvae require higher dietary VM levels than juvenile fish to achieve their developmental processes correctly. The National Research Council standard VM that incorporated into larvae feeds at 8 times the content recommended for juveniles gave the best results in terms of growth, survival, and also morphogenesis. However, the fact that the percentage of head and column deformities remained significant demonstrates the need to further refine the proportions of certain vitamins (particularly those known to be involved in bone and collagen synthesis, i.e., Vitamins A, D, and C) in the standard vitamin mix. Our results showed a temporal sequence of coordinated growth factor expression, involving BMP-4 and IGF-1, controlling the differentiation of osteoblasts and also revealed how this sequence could be disrupted by differences in the dietary level of certain vitamins (that need to be precisely identified), leading to the appearance of deformities.

\section{Perspectives and Significance}

The normal programmed development of a multicellular organism is a synchronized series of events driven by genetic instructions. An organism however, has the ability to respond to environmental/nutritional situations by adaptations during the critical early period of its life, which will permanently affect its physiology and/or morphology in a positive or negative way. This plasticity is of particular importance in cultured marine fish larvae, especially concerning their bone metabolism and the high frequency of skeletal deformities. One of the major bottlenecks for understanding skeletal deformities in fish is the lack of effective methods to characterize bone anomalies induced by nutrition early in life. This study initiates the characterization of the basis of fish skeletal abnormalities and brings into view new elements that should be considered for fish larvae feed composition.

\section{ACKNOWLEDGMENTS}

The authors are grateful to Viviane Verlhac from DSM Nutritional Products-France, who kindly provided all of the vitamins used in this work. The authors also thank Hervé Le Delliou for the feeds analyses and Helen McCombie for correcting the English.

\section{GRANTS}

This work was, in part, supported by FINEFISH, a Collective Research Project of the sixth Framework Programme of the European Union (Contract 012451).

\section{REFERENCES}

1. Allan EH, Ho PW, Umezawa A, Hata J, Makishima F, Gillespie MT, Martin TJ. Differentiation potential of a mouse bone marrow stromal cell line. J Cell Biochem 90: 158-169, 2003.

2. Balmer JE, Blomhoff R. Gene expression regulation by retinoic acid. $J$ Lipid Res 43: 1773-1808, 2002.

3. Cahu CL, Zambonino Infante JL, Barbosa V. Effect of dietary phospholipid level and phospholipid: neutral lipid value on the development of sea bass (Dicentrarchus labrax) larvae fed a compound diet. Br J Nutr 90: 21-28, 2003.

4. Dedi J, Takeuchi T, Seikai T, Watanabe T. Hypervitaminosis and safe levels of vitamin A for larval flounder (Paralichthys olivaceus) fed Artemia nauplii. Aquaculture 133: 135-146, 1995.

5. Dedi J, Takeuchi T, Seikai T, Watanabe T, Hosoya K. Hypervitaminosis A during vertebral morphogenesis in larval Japanese flounder. Fisheries Science 63: 466-473, 1997.

6. Escaffre AM, Zambonino Infante JL, Cahu CL, Mambrini M, Bergot P, Kaushik SJ. Nutritional value of soy protein concentrate for larvae of common carp (Cyprinus carpio) based on growth performance and digestive enzyme activities. Aquaculture 153: 63-80, 1997.

7. Gouillou-Coustans MF, Bergot P, Kaushik SJ. Dietary ascorbic acid needs of common carp (Cyprinus carpio) larvae. Aquaculture 161: 453 461, 1998.

8. Haga Y, Suzuki T, Kagechika H, Takeuchi T. A retinoic acid receptorselective agonist causes jaw deformity in the Japanese flounder, Paralichthys olivaceus. Aquaculture 221: 381-392, 2003.

9. Haga Y, Suzuki T, Takeuchi T. Retinoic acid isomers produce malformations in postembryonic development of the Japanese flounder, Paralichthys olivaceus. Zool Sci 19: 1105-1112, 2002.

10. Haga Y, Takeuchi T, Murayama Y, Ohta K, Fukunaga T. Vitamin D3 compounds induce hypermelanosis on the blind side and vertebral deformity in juvenile Japanese flounder Paralichthys olivaceus. Fisheries Science 70: 59-67, 2004.

11. Hughes FJ, Turner W, Belibasakis G, Martuscelli G. Effects of growth factors and cytokines on osteoblast differentiation. Periodontol 2000 41: 48-72, 2006.

12. Jurutka PW, Whitfield GK, Hsieh JC, Thompson PD, Haussler CA, Haussler MR. Molecular nature of the vitamin D receptor and its role in regulation of gene expression. Rev Endocr Metab Disord 2: 203-216, 2001.

13. Karsenty G. Minireview: Transcriptional control of osteoblast differentiation. Endocrinology 142: 2731-2733, 2001.

14. Kaushik SJ, Gouillou-Coustans MF, Cho CY. Application of the recommendations on vitamin requirements of finfish by NRC (1993) to salmonids and sea bass using practical and purified diets. Aquaculture 161: 463-474, 1998.

15. Lall SP, Lewis-McCrea LM. Role of nutrients in skeletal metabolism and pathology in fish-an overview. Aquaculture 267: 3-19, 2007.

16. National Research Council. Guide for the Care and Use of the Laboratory Animals. Washington, DC: National Academic Press, 1996. 
17. National Research Council. Nutrient Requirements of Fish. Washington DC: National Academy Press, 1993.

18. Ornsrud R, Graff IE, Hoie S, Totland GK, Hemre GI. Hypervitaminosis A in first-feeding fry of the Atlantic salmon (Salmo salar L.) Aquaculture Nutr 8: 7-13, 2002.

19. Péres A, Zambonino Infante JL, Cahu C. Dietary regulation of activities and mRNA levels of trypsin and amylase in sea bass (Dicentrarchus labrax) larvae. Fish Physiol Biochem 19: 145-152, 1998.

20. Ross SA, McCaffery PJ, Drager UC, De Luca LM. Retinoids in embryonal development. Physiol Rev 80: 1021-1054, 2000.

21. Suzuki T, Kurokawa T. Functional analyses of FGF during pharyngeal cartilage development in flounder (Paralichthys olivaceus) embryo. Zool Sci 13: 883-891, 1996.

22. Suzuki T, Oohara I, Kurokawa T. Hoxd-4 expression during pharyngeal arch development in flounder (Paralichthys olivaceus) embryos and effects of retinoic acid on expression. Zool Sci 15: 57-67, 1998.

23. Suzuki T, Oohara I, Kurokawa T. Retinoic acid given at late embryonic stage depresses sonic hedgehog and Hoxd-4 expression in the pharyngea area and induces skeletal malformation in flounder (Paralichthys olivaceus) embryos. Dev Growth Differ 41: 143-152, 1999.
24. Takeuchi T, Dedi J, Haga Y, Seikai T, Watanabe T. Effect of vitamin A compounds on bone deformity in larval Japanese flounder (Paralichthys olivaceus). Aquaculture 169: 165, 1998.

25. Villeneuve L, Gisbert E, Le Delliou H, Cahu CL, Zambonino Infante JL. Dietary levels of all-trans retinol affect retinoid nuclear receptor expression and skeletal development in European sea bass larvae. $\mathrm{Br} J$ Nutr 93: 791-801, 2005.

26. Villeneuve L, Gisbert E, Moriceau J, Cahu C, Zambonino Infante JL. Intake of different levels of vitamin A and polyunsaturated fatty acids during different developmental periods modifies the expression of morphogenesis genes in European sea bass (Dicentrarchus labrax). Br J Nutr 95: 677-687, 2006.

27. Wan M, Cao X. BMP signaling in skeletal development. Biochem Biophys Res Commun 328: 657, 2005.

28. Zambonino Infante JL, Cahu CL, Péres A. Partial substitution of diand tripeptides for native proteins in sea bass diet improves Dicentrarchus labrax larval development. J Nutr 127: 608-614, 1997.

29. Zambonino Infante JL, Cahu CL. Dietary modulation of some digestive enzymes and metabolic processes in developing marine fish: applications to diet formulation. Aquaculture 268: 98-105, 2007.

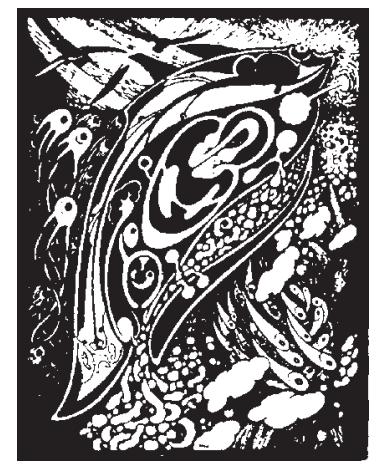

